\title{
Googling Musculoskeletal-Related Pain and Ranking of Medical Associations' Patient Information Pages: Google Ads Keyword Planner Analysis
}

Yoichiro Yamaguchi, MD; Deokcheol Lee, MD, PhD; Takuya Nagai, MD; Taro Funamoto, MD, PhD; Takuya Tajima, $\mathrm{MD}, \mathrm{PhD}$; Etsuo Chosa, MD, PhD

Department of Orthopaedic Surgery, Faculty of Medicine, University of Miyazaki, Miyazaki, Japan

\section{Corresponding Author:}

Yoichiro Yamaguchi, MD

Department of Orthopaedic Surgery

Faculty of Medicine

University of Miyazaki

5200 Kihara

Kiyotake

Miyazaki, 889-1692

Japan

Phone: 810985850986

Email: yoichiroh_yamaguchi@med.miyazaki-u.ac.jp

\section{Abstract}

Background: Most people currently use the internet to obtain information about many subjects, including health information. Thus, medical associations need to provide accurate medical information websites. Although medical associations have their own patient education pages, it is not clear if these websites actually show up in search results.

Objective: The aim of this study was to evaluate how well medical associations function as online information providers by searching for information about musculoskeletal-related pain online and determining the ranking of the websites of medical associations.

Methods: We conducted a Google search for frequently searched keywords. Keywords were extracted using Google Ads Keyword Planner associated with "pain” relevant to the musculoskeletal system from June 2016 to December 2019. The top 20 search queries were extracted and searched using the Google search engine in Japan and the United States.

Results: The number of suggested queries for "pain" provided by Google Ads Keyword Planner was 930 in the United States and 2400 in Japan. Among the top 20 musculoskeletal-related pain queries chosen, the probability that the medical associations' websites would appear in the top 10 results was 30\% in the United States and $45 \%$ in Japan. In five queries each, the associations' websites did not appear among the top 100 results. No significant difference was found in the rank of the associations' website search results $(P=.28)$.

Conclusions: To provide accurate medical information to patients, it is essential to undertake effective measures for search engine optimization. For orthopedic associations, it is necessary that their websites should appear among the top search results.

(J Med Internet Res 2020;22(8):e18684) doi: 10.2196/18684

\section{KEYWORDS}

Google; ad words; infodemiology; musculoskeletal-related pain; patient education; medical information

\section{Introduction}

\section{Justification}

Searching for information on the internet is now common practice. Medical information is no exception, and the term "consulting Dr. Google" has been popularized to represent searching for medical information on the internet [1]. Various studies have investigated the reliability and accuracy of medical information acquired on the internet [2-4]. However, there has been no research to specifically examine the extent to which medical information from websites supervised by medical associations is acquired from search results. 


\section{Background}

As of 2018, more than 100 million people in Japan (79.8\% of the total population) used the internet with various devices, including half the population aged 65-79 years [5]. Japan is an increasingly aging society, and many older people suffer from locomotive disorders [6]; thus, it can be assumed that these individuals use the internet to obtain information about their conditions. According to one survey, $21.2 \%$ of patients referred to medical information from a medical institution on the internet, and $12.1 \%$ of patients referred to the social networking services of a medical institution or the government before going to the hospital [7].

Among all currently available search engines, Google has an overwhelming market share in Japan, accounting for $91.2 \%$ of searches on computers and $99.1 \%$ of searches on mobile devices [8]. Many people with musculoskeletal pain such as lower back pain and sciatica use Google to obtain information about their conditions. In such situations, it is valuable to know the type of information that people actually obtain from internet searches. Many hospitals, companies, public interest groups, bloggers, and celebrities have posted medical information on websites. Accordingly, a substantial amount of inaccurate information about medical health has been posted globally [9]. We work in the orthopedic surgery department of a hospital and encounter many patients who are misled by inaccurate medical information about musculoskeletal-related pain. The Japan Medical Association states that it will support the health and cultural well-being of the Japanese population. Providing accurate medical information to patients is one of the missions of such medical associations, and orthopedic associations play a key role in the provision of online information about musculoskeletal-related pain.

Orthopedic associations have their own websites with patient education resources that provide information on symptoms and diseases. However, it is not known whether these websites provided by the orthopedic associations appear in the results of searches with search engines. Google Trends and Google Ads are often used to investigate what searches are actually performed on the internet. A relationship between Google's search volume increase and the influenza epidemic was noted based on such analyses [10-12]. In this study, we used the same tools to verify actual search queries and their relationship to orthopedic associations' website ranks. We also investigated seasonally varying varieties of musculoskeletal-related pain queries that were frequently searched. In addition, we investigated whether there is a more appropriate season for providing effective medical information for each symptom related to musculoskeletal-related pain. Based on this information, we investigated whether the associations' websites were able to provide suitable medical information to patients.

\section{Methods}

\section{Search Strategy for Data Extraction}

We extracted research volumes for the term "pain" (Japanese: "itami") and generated keywords using Google Ads Keywords Planner. The data were generated separately for each region: the United States (in English) and Japan (in Japanese). The data were collected in June 2020 and Google was used for all searches. The planner generated a list of proposed terms associated with "pain" and expressed the search volume for every month. The monthly search volumes for all keywords were extracted from June 2016 to December 2019. Total search volumes for the 4 years were calculated by population ratio and sorted in descending order. Among the generated keywords, two orthopedic doctors chose musculoskeletal pain-related keywords independently. The final list was refined by the senior author (EC). From this list, the top 20 search keywords were selected. Google searches were performed with the top 20 keywords and total hit websites were recorded. We employed Google Chrome without logging in to a Google account; we blocked location information and did not use the autocomplete function. We conducted the search in incognito mode. When searching, a proxy server was used. The search was performed through servers in Japan and the United States for each language. The Japanese Orthopedic Association (JOA) patient information pages [13] and the American Academy of Orthopedic Surgeons (AAOS) patient education pages [14] were selected as the association websites. The results of the searches were checked for the top 100 sites and those not displayed within the top 100 were ranked as over 100 .

\section{Statistical Analysis}

All pain-related suggested searches in a 4-year period in both Japan and the United States were collected, and the number of searches per 100 people in each country was calculated. The monthly average number of musculoskeletal-related pain searches from June 2016 to December 2019 was also calculated. Among the keywords ranked within the top 20, those common to the United States and Japan were compared with seasonal variations. The Kruskal-Wallis test, Mann-Whitney $U$ test, and Spearman rank correlation coefficient were used for statistical analysis of the search results. $P$ values of $<.05$ were considered to indicate a significant difference. Statistical analyses were performed using Statistical Package for the Social Sciences (IBM Corp Released 2012, IBM SPSS Statistics for Windows, Version 21.0. Armonk, NY, USA).

\section{Results}

The total number of generated keywords from "pain" was 930 in the United States and was 2400 in Japan. In Japan, the search term was "itami," a word that contains a Chinese character and Hiragana. In all generated queries, the average search volume ranged from 90 to 301,000 per month in the United States and from 140 to 135,000 per month in Japan. The search volume of the top 20 musculoskeletal pain-related queries ranged from 60,500 to 301,000 per month in the United States and from 22,200 to 135,000 per month in Japan. The population ratio was 0.85-4.99 per month per 100 people in the United States and was 0.88-4.94 per month per 100 people in Japan. No significant difference was found between the number of searches per population for the two countries (Mann-Whitney $U$ test $P=.67$ ). Regarding the association websites that appeared within the top 100 , the average rank was 16.47 ( 1 st to 35 th, mean 17 th) in the United States and was 24.47 (2nd to 95th, mean 7th) in Japan. Within the top 20 queries, the association websites ranked within 
the top 10 for $30 \%(6 / 20)$ of queries in the United States and for $45 \%(9 / 20)$ of queries in Japan. No significant difference was found between the number of ranked websites within the top 10 (Mann-Whitney $U$ test $P=.28$ ). The total search volume of the top 20 queries was 0.75 per 100 people in the United States and was 0.73 per 100 people in Japan (Table 1 and Table 2). As shown in Figure 1, the total search volume increased year after year. In the top 20 queries, the most common search queries in the United States and Japan were "sciatica," "lower back pain," "back pain," "knee pain," and "leg cramps" (Figure 2). Seasonal variation in the number of searches was found for "leg cramps," which was significantly higher in the summer in both the United States and Japan. No significant difference was found between search volume and the number of total hit websites for the top 20 queries (Figure 3).

Table 1. Top 20 search queries in the United States.

\begin{tabular}{|c|c|c|c|c|}
\hline Search queries & $\begin{array}{l}\text { Average search volume per } \\
\text { month }\end{array}$ & $\begin{array}{l}\text { Four-year total search vol- } \\
\text { ume (per } 100 \text { people) }\end{array}$ & Total hit websites & Association website rank \\
\hline sciatica & 301,000 & $15,491,000(4.99)$ & $35,400,000$ & 35 \\
\hline lower back pain & 246,000 & $11,862,000(3.82)$ & $664,000,000$ & 28 \\
\hline herniated disc & 165,000 & $7,957,500(2.56)$ & $5,010,000$ & 7 \\
\hline bursitis & 165,000 & $7,687,000(2.48)$ & $5,610,000$ & 8 \\
\hline knee pain & 135,000 & $6,926,000(2.23)$ & $278,000,000$ & 12 \\
\hline shoulder pain & 135,000 & $5,941,000(1.91)$ & $302,000,000$ & 7 \\
\hline carpal tunnel syndrome & 110,000 & $5,594,000(1.80)$ & $13,400,000$ & 1 \\
\hline muscle relaxers & 110,000 & $5,043,500(1.62)$ & $1,370,000$ & $>100$ \\
\hline heel pain & 110,000 & $4,869,000(1.57)$ & $143,000,000$ & 6 \\
\hline back pain & 90,500 & $4,624,000(1.49)$ & $1,510,000,000$ & 27 \\
\hline neck pain & 90,500 & $4,044,000(1.30)$ & $364,000,000$ & 19 \\
\hline muscle spasm & 90,500 & $4,038,000(1.30)$ & $11,400,000$ & 25 \\
\hline hip pain & 74,000 & $3,918,000(1.26)$ & $432,000,000$ & 17 \\
\hline sciatic nerve pain & 74,000 & $3,910,400(1.26)$ & $6,680,000$ & $>100$ \\
\hline piriformis syndrome & 74,000 & $3,680,000(1.19)$ & $1,800,000$ & $>100$ \\
\hline heel spur & 74,000 & $3,676,500(1.18)$ & $15,500,000$ & 7 \\
\hline foot pain & 60,500 & $3,237,000(1.04)$ & $1,440,000,000$ & $>100$ \\
\hline myalgia & 60,500 & $3,062,500(0.99)$ & $3,240,000$ & $>100$ \\
\hline leg cramps & 60,500 & $2,892,500(0.93)$ & $31,700,000$ & 23 \\
\hline hip bursitis & 60,500 & $2,639,600(0.85)$ & $5,910,000$ & 25 \\
\hline
\end{tabular}


Table 2. Top 20 search queries in Japan.

\begin{tabular}{|c|c|c|c|c|}
\hline Search queries (English translation) & $\begin{array}{l}\text { Average search volume } \\
\text { per month }\end{array}$ & $\begin{array}{l}\text { Four-year total search volume } \\
\text { (per } 100 \text { people) }\end{array}$ & Total hit websites & $\begin{array}{l}\text { Association website } \\
\text { rank }\end{array}$ \\
\hline zakotsushinkeitu (sciatica) & 135,000 & $6,250,000(4.94)$ & $5,870,000$ & 13 \\
\hline youtuu (lower back pain) & 90,500 & $4,737,000(3.74)$ & $83,300,000$ & 2 \\
\hline rokkanshinkeitsu (intercostal neuralgia) & 74,000 & $3,724,500(2.94)$ & 577,000 & $>100$ \\
\hline kensyouen (tendosynovitis) & 74,000 & $3,307,000(2.61)$ & $8,660,000$ & 3 \\
\hline komuragaeri (leg cramps) & 49,500 & $2,217,300(1.75)$ & 995,000 & $>100$ \\
\hline senaka no itami (back pain) & 40,500 & $2,120,800(1.68)$ & $26,600,000$ & 91 \\
\hline koshi ga itai (my lower back aches) & 40,500 & $2,103,600(1.66)$ & $35,900,000$ & 88 \\
\hline hiza no itami (knee pain) & 40,500 & $2,090,900(1.65)$ & $25,000,000$ & 7 \\
\hline ashi no ura itai (sole pain) & 40,500 & $2,081,400(1.64)$ & $26,800,000$ & 95 \\
\hline senaka ga itai (my back aches) & 33,100 & $1,721,300(1.36)$ & $28,000,000$ & $>100$ \\
\hline hiza ga itai (my knee aches) & 33,100 & $1,670,600(1.32)$ & $19,000,000$ & 23 \\
\hline senaka itai (back, pain) & 33,100 & $1,635,300(1.29)$ & $30,100,000$ & $>100$ \\
\hline kubi ga itai (my neck aches) & 33,100 & $1,580,000(1.25)$ & $38,800,000$ & 7 \\
\hline gojukata (painful shoulder at age 50s) & 33,100 & $1,476,200(1.17)$ & $8,650,000$ & 2 \\
\hline $\begin{array}{l}\text { henkeiseihizakansetsusho (osteoarthritis } \\
\text { of the knee) }\end{array}$ & 33,100 & $1,413,600(1.12)$ & $4,860,000$ & 2 \\
\hline kokansetsu itami (hip, pain) & 27,100 & $1,310,700(1.04)$ & $7,360,000$ & 5 \\
\hline shinkeitsu (neuralgia) & 27,100 & $1,224,600(0.97)$ & $7,660,000$ & 17 \\
\hline fukurahagi itai (calf, pain) & 22,200 & $1,163,900(0.92)$ & $1,900,000$ & 8 \\
\hline hiza itami (knee, pain) & 22,200 & $1,139,400(0.90)$ & $26,600,000$ & 4 \\
\hline shijukata (painful shoulder at age 40s) & 22,200 & $1,115,300(0.88)$ & $253,000,000$ & $>100$ \\
\hline
\end{tabular}

Figure 1. Total number of musculoskeletal-related searches in the United States and Japan (total monthly search volume of the top 20 search queries). Vertical axis: Searches per 100 people.

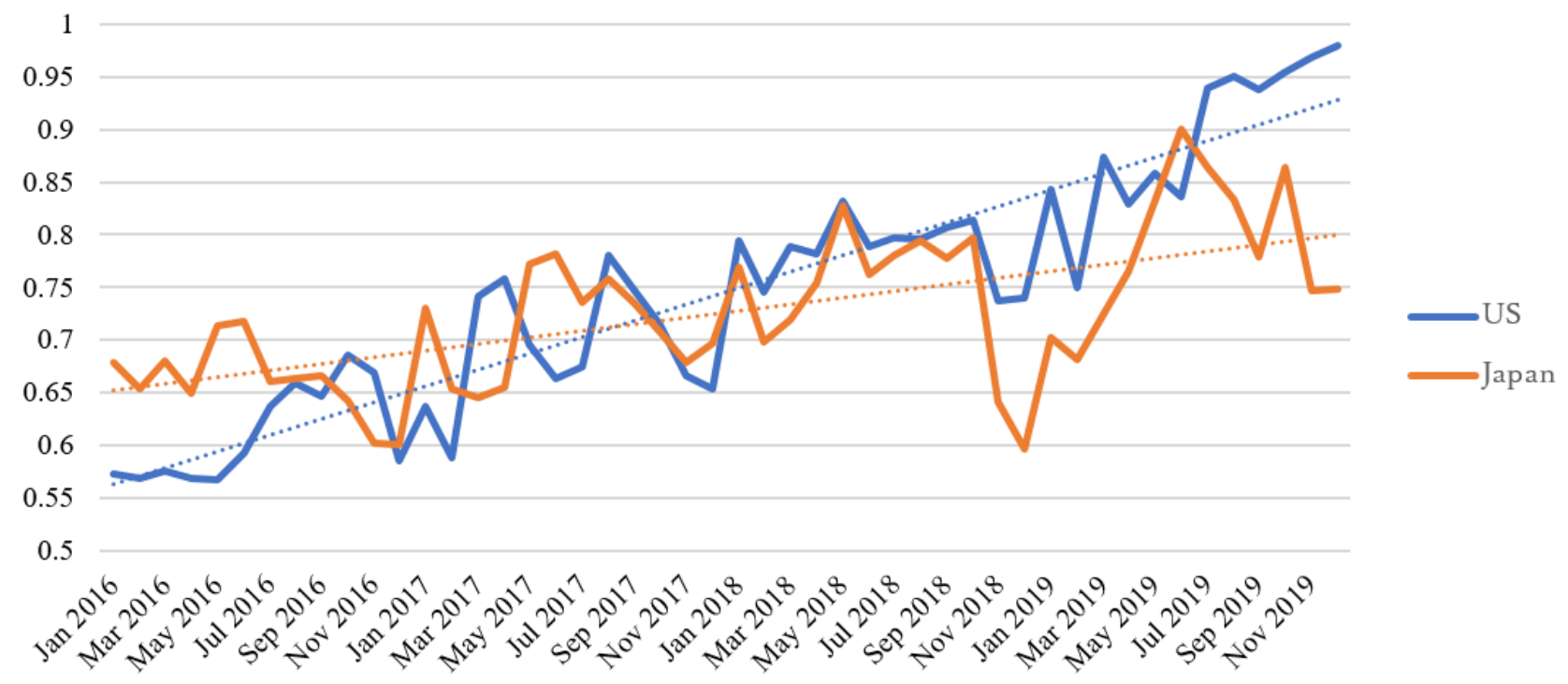


Figure 2. Comparison of musculoskeletal pain-related searches per month for each season (2016-2019) Vertical axis: Monthly searches per 10,000 people. ${ }^{\mathrm{a}}$ Differences between seasons (Kruskal-Wallis test); ${ }^{\mathrm{b}}$ Differences between the United States and Japan (Mann-Whitney U test).

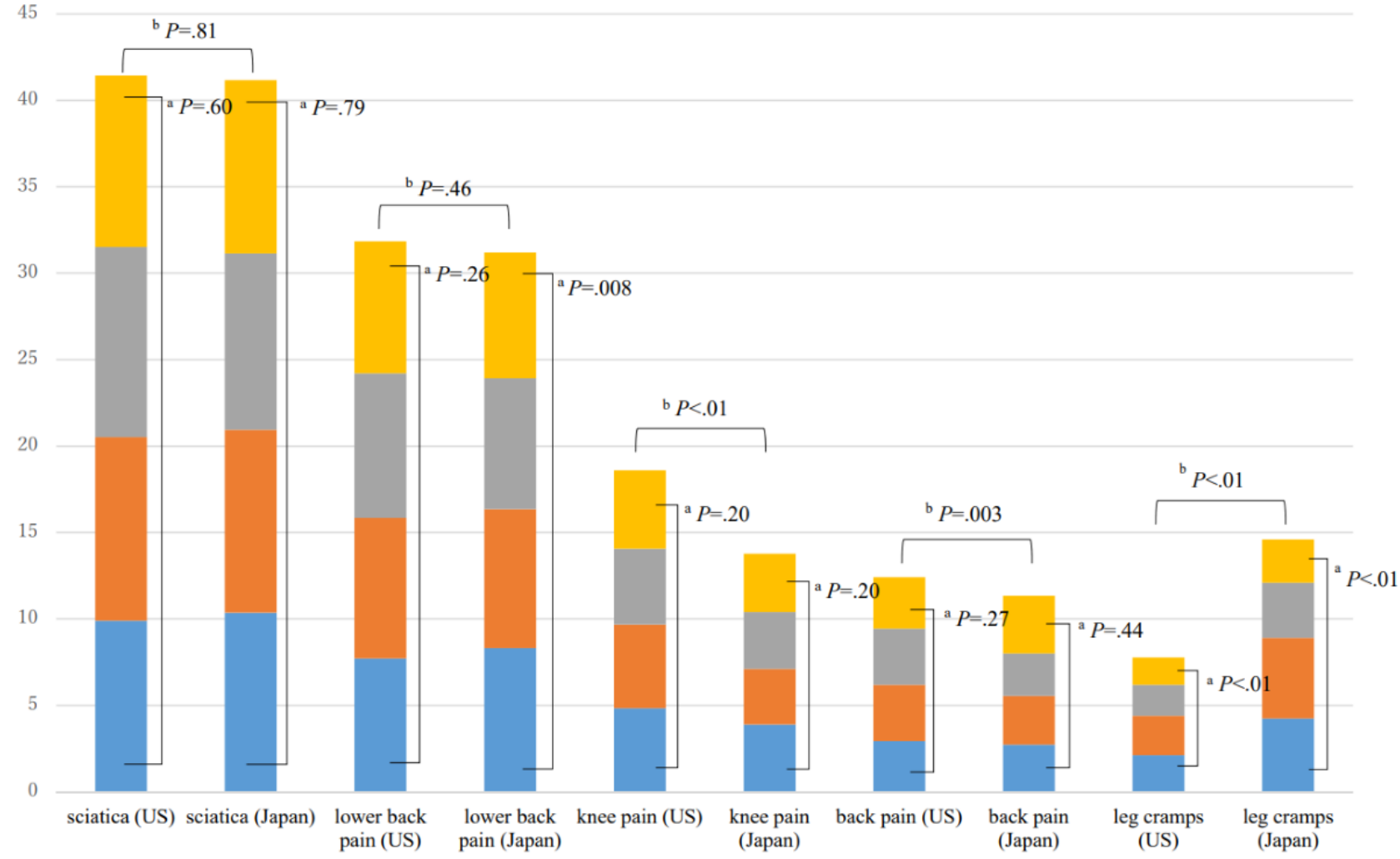

$\square$ Spring $\quad$ Summer $\square$ Fall $\square$ Winter

Figure 3. Search volumes and number of total hit websites. Vertical axis: Number of total hit websites (logarithmic scale). Horizontal axis: Four-year search volume per 100 people. No significant difference was observed in the relationship between the search volume and the number of total hit websites (Spearman rank correlation coefficient $=0.13$ ).

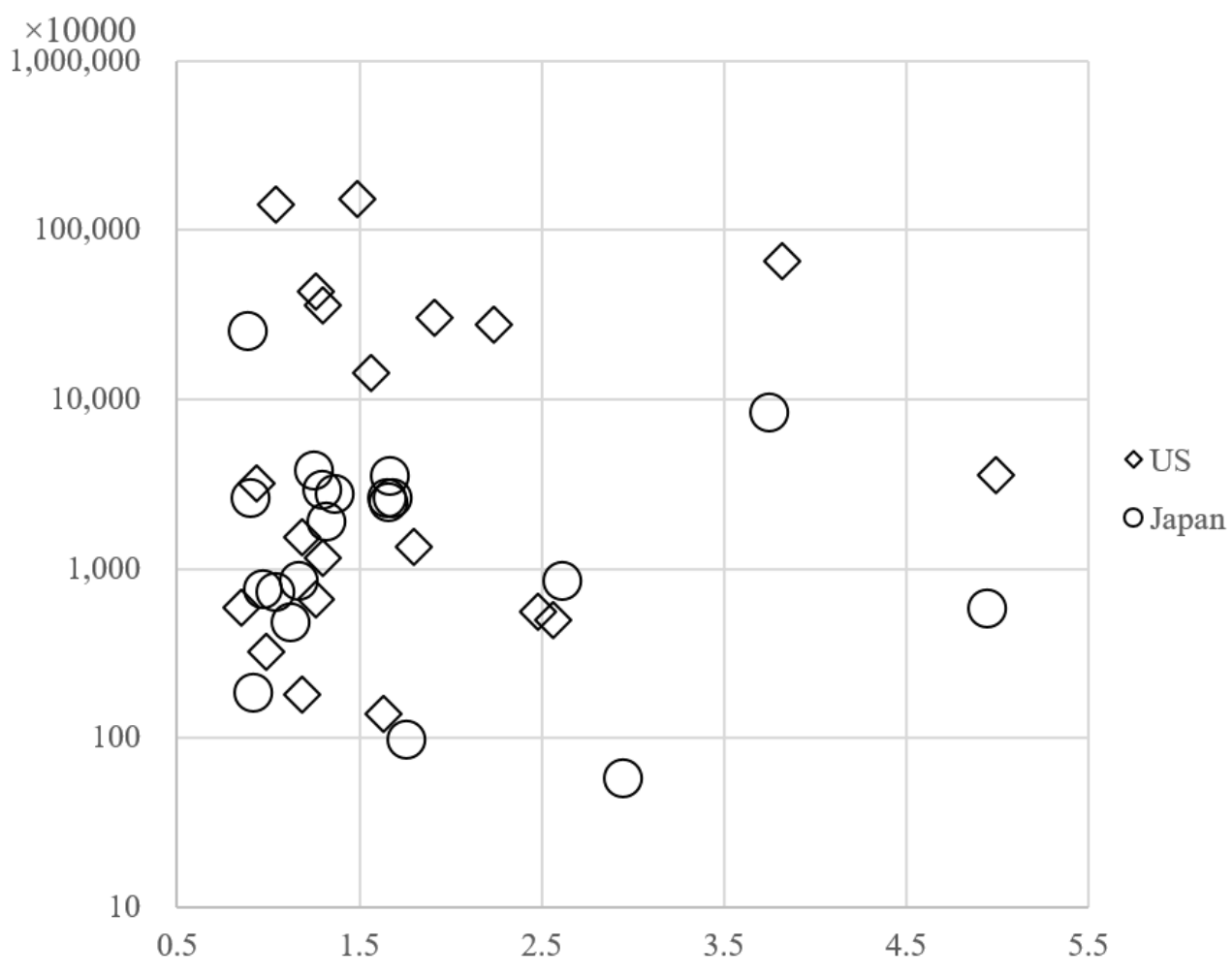




\section{Discussion}

This study is the first to examine how frequently the patient information pages of orthopedic associations appear when search terms related to musculoskeletal pain are entered. Based on the results of this study, we believe that there is a need for orthopedic associations to do more to provide medical information on the internet by optimizing their position in the search results for frequently searched symptom and disease-related terms.

The click-through rate for the first position in Google was $21.12 \%$, followed by $10.65 \%$ and $7.57 \%$. If the search result ranked 11 th, the click-through rate became only $1.46 \%$ [15]. In a German study, when 289 patients searched for medical information on the internet, only 5 clicked a link on the second or subsequent search result pages [16].

In the early 2000 s, over $60 \%$ of people in the United States and Australia reported that they had used the internet to search for medical information and were satisfied with the resulting health information and services [17-19]. More recently, 96\% of people in Australia reported searching for medical information online; of those, 63\% searched using smartphones [20]. Over time, it has become increasingly common for individuals to use online search engines when they need medical or health information.

According to many reports, inaccurate websites often appear among the top 10 results and provide erroneous information $[21,22]$. In the United Kingdom, Wikipedia sometimes appears more often in the search results than the National Health Service's website [23]. If members of the general public encounter websites containing incorrect information, it is difficult for them to assess its accuracy. In a US study, high school students with a science-focused education had difficulty distinguishing between reliable and unreliable medical sites, even though most of the information produced in the searches was inaccurate [24]. To solve health problems, government organizations need to work together to provide more accurate medical information on the web [9].

The algorithm used for Google searches is confidential; thus, many websites try to increase the quantity and quality of their traffic using organic search engine results. This practice is termed search engine optimization (SEO). At present, if items do not appear among search engine results, they are practically nonexistent.

In this study, we surveyed the search rankings of the patient information pages of two orthopedic associations and found that these pages are not likely to be viewed by patients seeking medical information with frequently searched queries. There was no significant difference in the number of searches per 100 people between the United States and Japan in the top 20 pages retrieved for musculoskeletal-related pain. Symptoms and illnesses are searched differently between the United States and
Japan. The common query "leg cramps" was searched much more often in Japan per 100 people and was searched more often in the summer in both the United States and Japan (Figure 2 ). The predominance in summer suggests a link to climate. Indeed, in the United Kingdom and Australia, the volume of searches related to leg cramps increased in summer [25]. Another study found that searches related to ankle swelling also increased in midsummer [26]. Heartburn-related searches increased during winter, as did heart failure hospitalizations $[10,27]$. These studies indicate that an increase in the search volume for a particular condition reflects an actual increase in the number of patients affected with that condition. Thus, when the search volume increases, it may be effective for medical associations to provide medical information to patients who need accurate information using social networking sites such as Facebook and Twitter. The act of conducting medical interventions via social media (ie, social media intervention) is reported to be an effective tool for enhancing public health [28]. In the future, it will be important to increase interventions in addition to disseminating medical information via social networking sites. The AAOS has a Twitter account, whereas the JOA currently does not (as of June 2020).

On December 6, 2017, Google made an official announcement about improving the quality of search results for medical and health matters [29]. After this statement was made, information from health professionals, specialists, and medical institutions should have become more readily available, and information sources such as blogs and websites dealing with folk medicine should have been excluded from searches. However, the websites of the two associations we focused on rarely appeared among the top 10 results, indicating that no dramatic change has in fact taken place. In that announcement, Google stated that health experts should make their websites appropriate for general users by avoiding the use of technical terms. Fortunately, personal blogs and unofficial websites that may have posted incorrect medical information tended not to appear in the search results owing to Google's corporate efforts.

The findings of our study suggest that better SEO is required to boost the ranking of medical associations' websites. If their websites were to achieve the highest ranking, ordinary patients could more readily obtain appropriate medical information. Of course, it is also necessary to include accurate medical information on the associations' patient information pages. An SEO strategy comprises two categories: on-page and off-page SEO. Details about this may be found in the Google Search Engine Optimization Starter Guide [30] and the Google Webmaster Guidelines [31]. Unfortunately, development of an SEO takes time. Daily updates and accurate articles need to be posted online to raise the rankings of the medical associations. In the future, a dual approach may be necessary, involving passive information transmission through companies such as Google, and active information transmission using social networking services such as Twitter and Facebook.

\section{Acknowledgments}

We thank Edanz Group for editing a draft of this manuscript. 


\section{Conflicts of Interest}

None declared.

\section{References}

1. Burke E, Harkins P, Saeed M, Salama M, Ahmed I. "Dr. Google" Will See You Now-Assessing the Quality of Information on Oesophageal Cancer on the Internet. J Gastrointest Surg 2019 Nov 25:Epub ahead of print. [doi: 10.1007/s11605-019-04416-5] [Medline: 31768833]

2. Murphy EP, Fenelon C, Murphy F, Baig MN, Murphy RP, Diack M, et al. Does Google ${ }^{\text {TM }}$ Have the Answers? The Internet-based Information on Pelvic and Acetabular Fractures. Cureus 2019 Oct 21;11(10):e5952 [FREE Full text] [doi: 10.7759/cureus.5952] [Medline: 31799093]

3. Okuhara T, Ishikawa H, Kato M, Okada M, Kiuchi T. A qualitative analysis of the beliefs of Japanese anti-influenza vaccination website authors. Heliyon 2018 Apr;4(4):e00609 [FREE Full text] [doi: 10.1016/j.heliyon.2018.e00609] [Medline: $\underline{29862370]}$

4. Pehora C, Gajaria N, Stoute M, Fracassa S, Serebale-O'Sullivan R, Matava CT. Are Parents Getting it Right? A Survey of Parents' Internet Use for Children's Health Care Information. Interact J Med Res 2015 Jun 22;4(2):e12 [FREE Full text] [doi: 10.2196/ijmr.3790] [Medline: 26099207]

5. Ministry of Internal Affairs and Communications Japan. Looking Back at the History of the Digital Economy in the Heisei Era. WHITE PAPER Information and Communications in Japan. Tokyo: The Ministry of Internal Affairs and Communications Japan; 2019. URL: https://www.soumu.go.jp/johotsusintokei/whitepaper/ja/r01/pdf/01honpen.pdf [accessed 2020-02-28]

6. Chosa E. [Locomotive syndrome and frailty. Locomotive syndrome due to the underlying disease of degenerative arthritis]. Clin Calcium 2012 Apr;22(4):49-57. [Medline: 22460511]

7. Director-General for Statistics and Information Policy HSO. Patient's Behavior Survey 2017 (Final Report). Tokyo: Ministry of Health, Labour and Welfare; 2019 Mar 15. URL: https://www.mhlw.go.jp/toukei/saikin/hw/jyuryo/17/kakutei.html [accessed 2020-07-13]

8. StatCounter. Search Engine Share Worldwide. URL: http://gs.statcounter.com/search-engine-market-share [accessed 2020-03-09]

9. King C, Judge C, Byrne A, Conlon N. Googling Allergy in Ireland: Content Analysis. J Med Internet Res 2020 May 13;22(5):e16763 [FREE Full text] [doi: 10.2196/16763] [Medline: $\underline{\text { 32401220] }}$

10. Ssendikaddiwa J, Lavergne R. Access to Primary Care and Internet Searches for Walk-In Clinics and Emergency Departments in Canada: Observational Study Using Google Trends and Population Health Survey Data. JMIR Public Health Surveill 2019 Nov 18;5(4):e13130 [FRE Full text] [doi: 10.2196/13130] [Medline: 31738175]

11. Kamiński M, Łoniewski I, Misera A, Marlicz W. Heartburn-Related Internet Searches and Trends of Interest across Six Western Countries: A Four-Year Retrospective Analysis Using Google Ads Keyword Planner. Int J Environ Res Public Health 2019 Nov 20;16(23):4591. [doi: 10.3390/ijerph16234591] [Medline: 31756947 ]

12. Seo D, Shin S. Methods Using Social Media and Search Queries to Predict Infectious Disease Outbreaks. Healthc Inform Res 2017 Oct;23(4):343-348 [FEE Full text] [doi: 10.4258/hir.2017.23.4.343] [Medline: 29181246]

13. The Japanese Orthopaedic Association. Patient Information. 2019. URL: https://www.joa.or.jp/public/index.html [accessed 2020-03-09]

14. The American Academy of Orthopaedic Surgeons. OrthiInfo. 2020. URL: https://orthoinfo.aaos.org [accessed 2020-03-09]

15. Internet Marketing Ninjas. Google Organic Clickthrough Study: Comparison of Google's CTR by position, industry, and query type. 2017. URL: https://www.internetmarketingninjas.com/additional-resources/google-ctr-white-paper.htm [accessed 2020-03-09]

16. Scullard P, Peacock C, Davies P. Googling children's health: reliability of medical advice on the internet. Arch Dis Child 2010 Aug;95(8):580-582. [doi: 10.1136/adc.2009.168856] [Medline: 20371593]

17. Wainstein BK, Sterling-Levis K, Baker SA, Taitz J, Brydon M. Use of the Internet by parents of paediatric patients. J Paediatr Child Health 2006 Sep;42(9):528-532. [doi: 10.1111/j.1440-1754.2006.00916.x] [Medline: $\underline{16925539]}$

18. Pew Internet \& American Life Project. Health Information Online. 2005 May 17. URL: https://www.pewresearch.org/ internet/2005/05/17/health-information-online/ [accessed 2020-03-09]

19. Pew Internet \& American Life Project. Wired for Health: How Californians Compare to the Rest of the Nation. 2003 Dec 15. URL: https://www.chcf.org/publication/wired-for-health-how-californians-compare-to-the-rest-of-the-nation/ [accessed 2020-07-13]

20. Yardi S, Caldwell PH, Barnes EH, Scott KM. Determining parents' patterns of behaviour when searching for online information on their child's health. J Paediatr Child Health 2018 Nov;54(11):1246-1254. [doi: 10.1111/jpc.14068] [Medline: 29864197]

21. Okuhara T, Ishikawa H, Kato M, Okada M, Kiuchi T. A qualitative analysis of the beliefs of Japanese anti-influenza vaccination website authors. Heliyon 2018 Apr;4(4):e00609 [FREE Full text] [doi: 10.1016/j.heliyon.2018.e00609] [Medline: 29862370] 
22. Downs JS, de Bruin WB, Fischhoff B. Parents' vaccination comprehension and decisions. Vaccine 2008 Mar 17;26(12):1595-1607. [doi: 10.1016/j.vaccine.2008.01.011] [Medline: 18295940 ]

23. Laurent MR, Vickers TJ. Seeking health information online: does Wikipedia matter? J Am Med Inform Assoc 2009;16(4):471-479 [FREE Full text] [doi: 10.1197/jamia.M3059] [Medline: 19390105]

24. Kortum P, Edwards C, Richards-Kortum R. The impact of inaccurate Internet health information in a secondary school learning environment. J Med Internet Res 2008 Jun 30;10(2):e17 [FREE Full text] [doi: 10.2196/jmir.986] [Medline: 18653441]

25. O'Keeffe ST. Summertime blues? A re-examination of the seasonality of web searches for restless legs and leg cramps. Sleep Med 2017 Sep;37:119-123. [doi: 10.1016/j.sleep.2017.06.017] [Medline: 28899521]

26. Liu F, Allan GM, Korownyk C, Kolber M, Flook N, Sternberg H, et al. Seasonality of Ankle Swelling: Population Symptom Reporting Using Google Trends. Ann Fam Med 2016 Jul;14(4):356-358 [FREE Full text] [doi: 10.1370/afm.1953] [Medline: 27401424]

27. Patel NJ, Nalluri N, Deshmukh A, Pant S, Shah N, Badheka AO, et al. Seasonal trends of heart failure hospitalizations in the United States: a national perspective from 2000 to 2011. Int J Cardiol 2014 May 15;173(3):562-563. [doi: 10.1016/j.ijcard.2014.03.122] [Medline: 24713458]

28. Bonar EE, Schneeberger DM, Bourque C, Bauermeister JA, Young SD, Blow FC, et al. Social Media Interventions for Risky Drinking Among Adolescents and Emerging Adults: Protocol for a Randomized Controlled Trial. JMIR Res Protoc 2020 May 13;9(5):e16688 [FREE Full text] [doi: 10.2196/16688] [Medline: 32401225]

29. Shin N. Improvement of search results quality about medical and health contents Internet: Google. 2017 Dec 6. URL: https:/ /webmaster-ja.googleblog.com/2017/12/for-more-reliable-health-search.html [accessed 2020-03-09]

30. The Google Search Quality team. Search Engine Optimization (SEO) Starter Guide. URL: https://support.google.com/ webmasters/answer/7451184?hl=en [accessed 2020-03-09]

31. The Google Search Quality team. Webmaster Guidelines. URL: https://support.google.com/webmasters/answer/35769?hl=en [accessed 2020-03-09]

\section{Abbreviations \\ AAOS: American Academy of Orthopedic Surgeons \\ JOA: Japanese Orthopedic Association \\ SEO: search engine optimization}

Edited by G Eysenbach; submitted 18.03.20; peer-reviewed by T Cruvinel, V Gianfredi; comments to author 20.04.20; revised version
received 04.06.20; accepted 11.06.20; published 14.08 .20
Please cite as:
Yamaguchi Y, Lee D, Nagai T, Funamoto T, Tajima T, Chosa E
Googling Musculoskeletal-Related Pain and Ranking of Medical Associations' Patient Information Pages: Google Ads Keyword
Planner Analysis
J Med Internet Res 2020;22(8):e18684
URL: $\underline{\text { https://www.jmir.org/2020/8/e18684 }}$
doi: $\underline{10.2196 / 18684}$
PMID: $\underline{32795991}$

(C) Yoichiro Yamaguchi, Deokcheol Lee, Takuya Nagai, Taro Funamoto, Takuya Tajima, Etsuo Chosa. Originally published in the Journal of Medical Internet Research (http://www.jmir.org), 14.08.2020. This is an open-access article distributed under the terms of the Creative Commons Attribution License (https://creativecommons.org/licenses/by/4.0/), which permits unrestricted use, distribution, and reproduction in any medium, provided the original work, first published in the Journal of Medical Internet Research, is properly cited. The complete bibliographic information, a link to the original publication on http://www.jmir.org/, as well as this copyright and license information must be included. 